SALAM; Jurnal Sosial \& Budaya Syar-i

FSH UIN Syarif Hidayatullah Jakarta

Vol. 6 No. 3 (2019), pp.239-264, DOl: 10.15408/sjsbs.v6i3.11535

\title{
Implementasi Peraturan Daerah Nomor 2 Tahun 2012 Tentang Pengawasan, Pengendalian, Pengedaran dan Pelarangan Penjualan Minuman Beralkohol di Kabupaten Bantul*
}

\author{
(Implementation of Regional Regulation No. 2 of 2012 concerning \\ Supervision, Control, Circulation and Prohibition of Sales of Alcoholic \\ Beverages in Bantul Regency)
}

\author{
Nareswari Kencana ${ }^{1}$ \\ Universitas Islam Negeri Syarif Hidayatullah Jakarta \\ doi $10.15408 /$ sjsbs.v6i3.11535
}

\begin{abstract}
.
The implementation of the law takes place because of a violation of law. In this case the law that has been violated must be enforced. It is through this law enforcement that the law becomes a reality. Bantul Regency is a district in the Special Region of Yogyakarta which is also an international tourism destination. One of the regional incomes is obtained from the tourism sector, then indirectly the culture and also the needs of tourists will enter the area. So, to regulate the circulation of alcoholic beverages in Bantul Regency Regional Regulation No. 2 of 2012 was formed, but until now law enforcement on the circulation and sale of alcoholic beverages is still experiencing problems. Some laws and regulations that regulate the circulation and sale of alcoholic beverages, allow the Regional Government to take steps in accordance with the conditions of their respective regions, while still taking into account the applicable laws and regulations.

Keywords: Alcoholic Beverages, Regional Regulations, Bantul
\end{abstract}

\begin{abstract}
Abstrak.
Pelaksanaan hukum berlangsung karena pelanggaran hukum. Dalam hal ini hukum yang telah dilanggar itu harus ditegakkan. Melalui penegakan hukum inilah hukum menjadi kenyataan. Kabupaten Bantul merupakan suatu kabupaten di Daerah Istimewa Yogyakarta yang juga merupakan destinasi pariwisata Internasional. Pendapatan daerah didapatkan salah satunya dari sektor pariwisata tersebut, maka secara tidak langsung budaya dan juga kebutuhan para wisatawan akan masuk ke dalam daerah. Maka untuk mengatur peredaran minuman beralkohol di Kabupaten Bantul dibentuklah Peraturan Daerah Nomor 2 Tahun 2012, namun sampai saat ini penegakan hukum terhadap pengedaran dan penjualan minuman beralkohol masih mengalami kendala. Beberapa peraturan perundang-undangan yang mengatur pengedaran dan penjualan minuman beralkohol, memungkinkan Pemerintah Daerah untuk mengambil langkah sesuai kondisi daerah masing-masing, dengan tetap memperhatikan peraturan perundang-undangan yang berlaku.

Kata Kunci: Minuman Beralkohol, Peraturan Daerah, Bantul
\end{abstract}

*Diterima: 17 Mei 2019, Revisi: 23 Mei 2019, Dipublikasi 13 Juni 2019.

1 Nareswari Kencana adalah dosen Ilmu Hukum Fakultas Syariah Hukum, Universitas Islam Negeri Syarif Hidayatullah, Jakarta. Alamat Jl. Ir. H. Juanda No. 95 Ciputat Tangsel Banten Indonesia. Email: nareswari.kencana23@gmail.com. 


\section{Pendahuluan}

Indonesia merupakan negara hukum sesuai dengan amanat Pasal 1 ayat (3) Undang-Undang Dasar Negara Republik Indonesia Tahun 1945 (UUD NRI 1945). Hukum berfungsi sebagai perlindungan kepentingan manusia. Agar kepentingan manusia terlindungi, hukum harus dilaksanakan. Konstitusi telah mengamanatkan kepada daerah untuk mengatur dan mengurus sendiri urusan pemerintahan menurut asas otonomi dan tugas pembantuan. Hal ini tercantum dalam Pasal 18 UUD NRI 1945.

Sistem penyelenggaraan pemerintahan di Indonesia meliputi sistem pemerintahan pusat dan sistem pemerintahan daerah. Praktik penyelenggaraan pemerintahan dalam hubungan antar pemerintah dikenal dengan konsep sentralisasi dan desentralisasi. Konsep sentralisasi menunjukkan karakteristik sebagian kewenangan urusan pemerintahan yang menjadi kewajiban pemerintah, diberikan kepada pemerintah daerah. ${ }^{2}$

Otonomi daerah merupakan esensi pemerintahan desentralisasi. Di dalam otonomi hubungan kewenangan antara pusat dan daerah, antara lain bertalian dengan cara pembagian urusan penyelenggaraan pemerintah atau cara menentukan urusan rumah tangga daerah. ${ }^{3}$ Di dalam negara kesatuan, otonomi daerah lebih terbatas dibanding dengan negara yang berbentuk federasi. Kewenangan mengatur dan mengurus rumah tangganya sendiri di daerah kesatuan meliputi segenap kewenangan pemerintah daerah kecuali beberapa unsur yang dipegang oleh pemerintah pusat ${ }^{4}$

Permasalahan penting di daerah otonom adalah masalah kesehatan, sosial dan kesejahteraan masyarakat. Kesehatan merupakan kebutuhan dasar setiap individu masyarakat yang harus dipenuhi oleh setiap bangsa dan negara. Termasuk kewajiban negara untuk memproteksi masyarakatnya agar tidak mendapatkan minuman atau makanan berbahaya yang dapat menyebabkan sakit bahkan kematian.

Minuman keras atau minuman beralkohol merupakan minuman yang berbahaya dan dapat menurunkan derajat kesehatan seseorang selain itu pula dapat menurunkan moral masyarakat suatu daerah bahkan masyarakat suatu negara. Peredaran minuman beralkohol tidak dapat lepas dari masyarakat Indonesia khususnya Masyarakat di Kabupaten Bantul. Mengingat Indonesia adalah negara tujuan pariwisata dan banyak unsur budaya luar yang mau tidak mau akan masuk ke dalam budaya masyarakat Indonesia. Oleh karena itu, perlu dibentuk suatu peraturan yang mengatur mengenai pengawasan penjualan minuman beralkohol.

\section{h. 11 .}

2 Siswanto Sunarno, Hukum Pemerintahan Daerah di Indonesia, (Jakarta: Sinar Grafika, 2006),

\footnotetext{
3 Ni'matul Huda, Hukum Pemerintah Daerah, (Bandung: Nusa Media, 2012), h. 83.

4 J. Kaloh, Mencari Bentuk Otonomi Daerah, (Jakarta: Rineka Cipta, 2002), h. 3.
} 
Kabupaten Bantul merupakan suatu kabupaten di Daerah Istimewa Yogyakarta yang juga adalah destinasi pariwisata Internasional. Pendapatan daerah didapatkan salah satunya dari sektor pariwisata tersebut, maka secara tidak langsung budaya dan juga kebutuhan para wisatawan akan masuk ke dalam daerah. Maka untuk mengatur peredaran minuman beralkohol di Kabupaten Bantul dibentuklah Peraturan Daerah Nomor 2 Tahun 2012 mengenai Pengawasan, Pengendalian, Pengedaran dan Pelarangan Penjualan Minuman Beralkohol di Kabupaten Bantul.

Pelaksanaan hukum berlangsung karena pelanggaran hukum. Dalam hal ini hukum yang telah dilanggar itu harus ditegakkan. Melalui penegakan hukum inilah hukum menjadi kenyataan. Ada tiga unsur yang selalu harus diperhatikan dalam penegakan hukum, yaitu: kepastian hukum (rechtssicherheit), kemanfaatan (zweckmassigkeit) dan keadilan (gerechtigkeit). ${ }^{5}$

Salah satu prinsip dalam negara hukum adalah pemerintahan berdasarkan peraturan perundang-undangan, dengan kata lain setiap tindakan hukum pemerintah baik dalam menjalankan fungsi pengaturan maupun fungsi pelayanan harus didasarkan pada wewenang yang diberikan oleh peraturan perundang-undangan yang berlaku. Hal tersebut sesuai dengan pendapat F.A.M. Stoink JG Stenbeck sebagaimana dikutip oleh Ridwan HR yang menyatakan bahwa untuk dapat melaksanakan dan menegakkan ketentuan hukum positif perlu wewenang, tanpa wewenang tidak dapat dibuat keputusan yuridis yang bersifat konkret. ${ }^{6}$

Pengedaran dan penjualan minuman beralkohol merupakan permasalahan sosial yang perlu mendapatkan perhatian serius semua pihak, baik aparat pemerintah, tokoh masyarakat maupun masyarakat pada umumnya karena bertentangan dengan nilai-nilai sosial, keagamaan, ketertiban dan seluruh aspek perikehidupan masyarakat. Minuman beralkohol merupakan produk yang dapat menurunkan derajat kesehatan dan moral bangsa serta bertentangan dengan visi Kabupaten Bantul sendiri yakni sejahtera, demokratis dan agamis, sehingga perlu dilakukan adanya pengawasan dan pengendalian terhadap pengedarannya, dan pelarangan penjualannya di Kabupaten Bantul. ${ }^{7}$

Menurut Pasal 3 ayat (2) Peraturan Bupati Bantul Nomor 4 Tahun 2007 tentang Perubahan Keputusan Bupati Bantul Nomor 493 Tahun 2001 tentang

5 Sudikno Mertokusumo, Mengenal Hukum, Suatu Pengantar, (Yogyakarta: Liberty, 2008), h, 134.

6 Ridwan.HR, Hukum Administrasi Negara, (Yogyakarta: UII Press, 2002), h. 162.

7 Dikutip dari Peraturan Daerah Kabupaten Bantul Nomor 2 Tahun 2012 bagian menimbang. 
Petunjuk Pelaksanaan Peraturan Daerah Kabupaten Bantul Nomor 15 Tahun 2001 tentang Retribusi Izin Gangguan yang menyatakan bahwa: ${ }^{8}$

Dalam rangka pengawasan dan pengendalian peredaran minuman beralkohol di Kabupaten Bantul, dilarang mengeluarkan izin gangguan untuk kegiatan produksi, peredaran dan atau penjualan minuman beralkohol, sebelum ditetapkan Peraturan Daerah yang mengatur ketentuan produksi, peredaran, penyimpanan dan/atau penjualan minuman beralkohol.

Sampai saat ini penegakan hukum terhadap pengedaran dan penjualan minuman beralkohol masih mengalami kendala dalam pengawasan, pengendalian, pengedaran dan pelarangan penjualan minuman beralkohol di Kabupaten Bantul. Beberapa peraturan perundang-undangan yang mengatur pengedaran dan penjualan minuman beralkohol, memungkinkan Pemerintah Daerah untuk mengambil langkah sesuai kondisi daerah masing-masing, dengan tetap memperhatikan peraturan perundang-undangan yang berlaku.

Peraturan Daerah Kabupaten Bantul Nomor 2 Tahun 2012 mengatur tentang Pengawasan, Pengendalian, Pengedaran dan Pelarangan Penjualan Minuman Beralkohol. Namun demikian bukan berarti Peraturan Daerah Kabupaten Bantul Nomor 2 Tahun 2012 akan melegalkan pengedaran dan penjualan minuman beralkohol di Kabupaten Bantul, karena berdasarkan Peraturan Daerah Kabupaten Bantul Nomor 2 Tahun 2012, minuman beralkohol hanya dapat dijual di tempat-tempat yang semestinya, yaitu pada hotel berbintang 3, hotel berbintang 4, dan hotel berbintang 5, serta Restoran dengan Tanda Talam Selaka dan Talam Kencana, Bar termasuk di dalamnya pub dan klab malam, karena hal tersebut sangat berkaitan dengan ketentuan yang mengatur mengenai kegiatan kepariwisataan. Namun dalam pelaksanaannya perlu diatur suatu mekanisme yang sangat ketat sebagaimana ditetapkan dalam Peraturan Daerah Kabupaten Bantul Nomor 2 Tahun 2012. Dalam pelaksanaannya perlu ditetapkan suatu peraturan pelaksanaan yang mengatur secara pasti dan tegas serta jelas mengenai mekanisme penegakan hukum Peraturan Daerah Nomor 2 Tahun 2012 tersebut.

Berdasarkan data yang penulis dapatkan dari Kepolisian Resort Bantul, diperoleh data bahwa dari tahun 2013 hingga bulan September 2016 jumlah pelanggaran terhadap Peraturan Daerah Kabupaten Bantul Nomor 2 Tahun 2012 cenderung mengalami kenaikan. Data dari bulan Juni 2013 sebanyak 18 pelanggaran, tahun 2014 sebanyak 68 pelanggaran, tahun 2015 sebanyak 75

8 Pasal 3 ayat (2) Peraturan Bupati Bantul Nomor 4 Tahun 2007 tentang Perubahan Keputusan Bupati Bantul Nomor 493 Tahun 2001 tentang Petunjuk Pelaksanaan Peraturan Daerah Kabupaten Bantul Nomor 15 Tahun 2001 tentang Retribusi Izin Gangguan. 
pelanggaran dan sampai bulan September 2016 sebanyak 59 pelanggaran terhadap Peraturan Daerah Kabupaten Bantul Nomor 2 Tahun 2012.9

Pada dasarnya dengan diterbitkannya Peraturan Daerah Kabupaten Bantul Nomor 2 Tahun 2012 tersebut pemerintah daerah bermaksud untuk melakukan pengawasan, pengendalian dan pelarangan penjualan minuman beralkohol. Akan tetapi kenyataannya hingga saat ini masih banyak penjualan minuman beralkohol secara illegal serta penggunaan minuman beralkohol yang dioplos di Kabupaten Bantul hal tersebut menimbulkan keresahan dan gangguan ketertiban di masyarakat.

\section{Kendala dalam Implementasi Peraturan Daerah Tentang Minuman Beralkohol di Kabupaten Bantul}

Otonomi daerah bisa diartikan sebagai kewajiban yang dikuasakan kepada daerah otonom untuk mengatur dan mengurus sendiri urusan pemerintahan dan kepentingan masyarakat setempat menurut aspirasi masyarakat untuk meningkatkan daya guna dan juga hasil guna penyelenggaraan pemerintahan dalam rangka pelayanan terhadap masyarakat dan pelaksanaan pembangunan sesuai dengan peraturan perundang-undangan. Sedangkan yang dimaksud dengan kewajiban yaitu kesatuan masyarakat hukum yang memiliki batas-batas wilayah yang berwenang mengatur pemerintahan serta kepentingan masyarakatnya sesuai prakarsa sendiri berdasarkan keinginan dan suara masyarakat.

Sebagai suatu daerah yang otonom, Pemerintah daerah mempunyai wewenang dalam mengeluarkan suatu Peraturan, dimana salah satu tujuannya adalah guna menjamin kepastian hukum dan menciptakan serta memelihara ketentraman dan ketertiban umum. Kepastian hukum dan penegakan Peraturan Daerah dalam penyelenggaraan pemerintahan, tentu tidak terlepas dari terciptanya keamanan dan ketertiban masyarakat, yang dalam perwujudannya diperlukan suatu kemampuan manajemen dan profesionalisme dalam menangani berbagai pelanggaran-pelanggaran menyangkut ketertiban sehingga hasil yang dicapai sesuai dengan apa yang diharapkan.

Ketertiban umum dan ketenteraman masyarakat adalah suatu keadaan dinamis yang memungkinkan Pemerintah, Pemerintah Daerah dan masyarakat dapat melakukan kegiatannya dengan tenteram, tertib dan teratur. Memang dirasakan oleh berbagai kalangan bahwa suatu Peraturan Daerah yang sudah diberlakukan secara efektif tidak pernah disosialisasikan oleh pemerintah daerah bersama aparat kepolisian atau instansi terkait, sehingga pemahaman masyarakat akan pentingnya Peraturan Daerah ini amat dangkal.

${ }_{9}$ Data diperoleh dari Satuan Sabhara Polres Bantul dari tahun 2013-2016 pada tanggal 10 Januari 2017. 
Berdasarkan hasil wawancara penulis dengan Teguh Nur Triono, selaku Kasi Pengkajian, Pengawasan dan Pengendalian Satuan Polisi Pamong Praja (Satpol PP) Kabupaten Bantul, ${ }^{10}$ diperoleh keterangan bahwa:

“...kendala yang dihadapi dalam penegakan Perda Kabupaten Bantul Nomor 2 Tahun 2012 adalah masih minimnya sumber daya manusia di bidang intelijen guna memberikan masukan/informasi terkait peredaran minuman beralkohol; serta pemberian vonis denda yang tidak membuat efek jera bagi pelanggar Perda Nomor 2 Tahun 2012..."

Menurut Sismadi, selaku Kasi Penindakan Satuan Polisi Pamong Praja (Satpol PP) Kabupaten Bantul, ${ }^{11}$ diperoleh keterangan bahwa:

“...kendala dalam penegakan Perda Nomor 2 Tahun 2012 adalah personil yang sangat terbatas serta prasarana yang kurang memadai terutama tempat penyidikan..."

Berdasarkan hasil wawancara penulis dengan Anjar Arintaka Putra, selaku Kepala Bidang Penegakan Perda Satuan Polisi Pamong Praja (Satpol PP) Kabupaten Bantul,12 diperoleh keterangan bahwa: “...kendala yang dialami dalam menegakkan Perda Nomor 2 Tahun 2012 adalah:

a. Sarana dan Prasarana berupa kendaraan, ruang penyidikan, ketersediaan peralatan tugas dan lain-lain

b. Koordinasi, ada beberapa tugas operasi dan patroli yang sudah bocor

c. Anggaran, ketersediaan anggaran sangat menunjang pelaksanaan kegiatan di lapangan.

Hal senada diungkapkan oleh Andri Kusmiarno, selaku Staf Penyidik PPNS Satuan Polisi Pamong Praja (Satpol PP) Kabupaten Bantul, ${ }^{13}$ yang menyatakan bahwa:

“...kendala yang dialami dalam menegakkan Perda Nomor 2 Tahun 2012 adalah: Sarana dan Prasarana berupa kendaraan, ruang penyidikan, ketersediaan peralatan tugas dan lain-lain; Koordinasi yaitu ada beberapa tugas operasi dan patroli yang sudah bocor; serta Anggaran yaitu ketersediaan anggaran sangat menunjang pelaksanaan kegiatan di lapangan..."

${ }^{10}$ Wawancara dengan Teguh Nur Triono, selaku Kasi Pengkajian, Pengawasan dan Pengendalian Satuan Polisi Pamong Praja (Satpol PP) Kabupaten Bantul, pada tanggal 14 Maret 2017.

${ }^{11}$ Wawancara dengan Sismadi, selaku Kasi Penindakan Satuan Polisi Pamong Praja (Satpol PP) Kabupaten Bantul, pada tanggal 14 Maret 2017.

${ }^{12}$ Wawancara dengan Anjar Arintaka Putra, selaku Kepala Bidang Penegakan Perda Satuan Polisi Pamong Praja (Satpol PP) Kabupaten Bantul, pada tanggal 15 Maret 2017.

${ }^{13}$ Wawancara dengan Andri Kusmiarno, selaku Staf Penyidik PPNS Satuan Polisi Pamong Praja (Satpol PP) Kabupaten Bantul, pada tanggal 15 Maret 2017. 
Berdasarkan hasil wawancara penulis dengan Sri Hartati, selaku Staf Penyidik PPNS Satuan Polisi Pamong Praja (Satpol PP) Kabupaten Bantul, ${ }^{14}$ diperoleh keterangan bahwa:

“...kendala-kendala yang dihadapi dalam penegakan Perda Nomor 2 Tahun 2012 adalah adanya kebocoran informasi, para penjual semakin pintar dalam menyembunyikan barang ilegal, serta modus transaksi yang semakin modern hanya dengan lewat HP..."

Berdasarkan hasil wawancara penulis dengan Teguh Nur Triono, selaku Kasi Pengkajian, Pengawasan dan Pengendalian Satuan Polisi Pamong Praja (Satpol PP) Kabupaten Bantul, ${ }^{15}$ diperoleh keterangan bahwa:

“... tanggapan masyarakat mengenai penegakan Perda Nomor 2 Tahun 2012 adalah masyarakat merasa senang/puas apabila mendengar, melihat, membaca berita adanya penegakan atas Perda Kabupaten Bantul Nomor 2 Tahun 2012 yang dipublis melalui media, baik melalui media cetak maupun media elektronik. Masyarakat juga merasa cukup senang dengan adanya sosialisasi Perda Nomor 2 Tahun 2012, dimana hal ini terbukti banyak yang hadir dan banyak pertanyaan yang diajukan masyarakat terkait Perda Nomor 2 Tahun 2012..."

Menurut Sismadi, selaku Kasi Penindakan Satuan Polisi Pamong Praja (Satpol PP) Kabupaten Bantul, ${ }^{16}$ diperoleh keterangan bahwa:

“...tanggapan masyarakat mengenai penegakan Perda Nomor 2 Tahun 2012 cukup bagus, karena denda pelanggar Perda Nomor 2 Tahun 2012 di Bantul cukup tinggi. Sedangkan tanggapan masyarakat mengenai sosialisasi masih dirasa kurang karena belum bisa dilaksanakan di seluruh wilayah pedukuhan..."

Berdasarkan hasil wawancara penulis dengan Anjar Arintaka Putra, selaku Kepala Bidang Penegakan Perda Satuan Polisi Pamong Praja (Satpol PP) Kabupaten Bantul, ${ }^{17}$ diperoleh keterangan bahwa

“...apresiasi yang cukup bagus dari berbagai kalangan atas penegakan Perda Nomor 2 Tahun 2012 yang selama ini dilaksanakan oleh Satpol PP dan Polisi. Apresiasi ini berasal dari kalangan DPRD DIY, DPRD Bantul, Kecamatan, Desa dan Warga masyarakat. Masyarakat juga sangat merespon dengan baik, apalagi akhir-akhir ini ada banyak korban miras yang berjatuhan..."

${ }^{14}$ Wawancara dengan Sri Hartati, selaku Staf Penyidik PPNS Satuan Polisi Pamong Praja (Satpol PP) Kabupaten Bantul, pada tanggal 15 Maret 2017.

${ }^{15}$ Wawancara dengan Teguh Nur Triono, selaku Kasi Pengkajian, Pengawasan dan Pengendalian Satuan Polisi Pamong Praja (Satpol PP) Kabupaten Bantul, pada tanggal 14 Maret 2017.

${ }^{16}$ Wawancara dengan Sismadi, selaku Kasi Penindakan Satuan Polisi Pamong Praja (Satpol PP) Kabupaten Bantul, pada tanggal 14 Maret 2017.

17 Wawancara dengan Anjar Arintaka Putra, selaku Kepala Bidang Penegakan Perda Satuan Polisi Pamong Praja (Satpol PP) Kabupaten Bantul, pada tanggal 15 Maret 2017. 
Hal senada diungkapkan Andri Kusmiarno, selaku Staf Penyidik PPNS Satuan Polisi Pamong Praja (Satpol PP) Kabupaten Bantul, ${ }^{18}$ yang menyatakan bahwa:

“...apresiasi yang cukup bagus dari berbagai kalangan atas penegakan Perda Nomor 2 Tahun 2012 yang selama ini dilaksanakan oleh Satpol PP dan Polisi. Apresiasi ini berasal dari kalangan DPRD DIY, DPRD Bantul, Kecamatan, Desa dan Warga masyarakat. Masyarakat juga sangat merespon dengan baik, apalagi akhir-akhir ini ada banyak korban miras yang berjatuhan..."

Sri Hartati, selaku Staf Penyidik PPNS Satuan Polisi Pamong Praja (Satpol PP) Kabupaten Bantul, ${ }^{19}$ juga menyatakan bahwa:

“...apresiasi yang cukup bagus dari berbagai kalangan atas penegakan Perda Nomor 2 Tahun 2012 yang selama ini dilaksanakan oleh Satpol PP dan Polisi. Apresiasi ini berasal dari kalangan DPRD DIY, DPRD Bantul, Kecamatan, Desa dan Warga masyarakat. Masyarakat juga sangat merespon dengan baik, apalagi akhir-akhir ini ada banyak korban miras yang berjatuhan..."

Berdasarkan hasil wawancara penulis dengan Teguh Nur Triono, selaku Kasi Pengkajian, Pengawasan dan Pengendalian Satuan Polisi Pamong Praja (Satpol PP) Kabupaten Bantul, 20 diperoleh keterangan bahwa: “...minuman beralkohol banyak beredar di tempat-tempat hiburan malam seperti tempat karaoke, namun tempat karaoke yang ada adalah tempat hiburan yang tidak legal/tidak berijin..."

Menurut Sismadi, selaku Kasi Penindakan Satuan Polisi Pamong Praja (Satpol PP) Kabupaten Bantul, ${ }^{21}$ diperoleh keterangan bahwa peredaran minuman beralkohol hampir merata di seluruh wilayah Kabupaten Bantul terutama di tempat wisata pantai. Sedangkan menurut Anjar Arintaka Putra, selaku Kepala Bidang Penegakan Perda Satuan Polisi Pamong Praja (Satpol PP) Kabupaten Bantul,22 diperoleh keterangan bahwa peredaran minuman beralkohol hampir merata di seluruh kecamatan se Kabupaten Bantul, tapi yang paling banyak ada di lokasi-lokasi wisata. Hal senada diungkapkan Andri Kusmiarno, selaku Staf Penyidik PPNS Satuan Polisi Pamong Praja (Satpol PP)

\footnotetext{
${ }^{18}$ Wawancara dengan Andri Kusmiarno, selaku Staf Penyidik PPNS Satuan Polisi Pamong Praja (Satpol PP) Kabupaten Bantul, pada tanggal 15 Maret 2017.

${ }^{19}$ Wawancara dengan Sri Hartati, selaku Staf Penyidik PPNS Satuan Polisi Pamong Praja (Satpol PP) Kabupaten Bantul, pada tanggal 15 Maret 2017.

${ }^{20}$ Wawancara dengan Teguh Nur Triono, selaku Kasi Pengkajian, Pengawasan dan Pengendalian Satuan Polisi Pamong Praja (Satpol PP) Kabupaten Bantul, pada tanggal 14 Maret 2017.

${ }^{21}$ Wawancara dengan Sismadi, selaku Kasi Penindakan Satuan Polisi Pamong Praja (Satpol PP) Kabupaten Bantul, pada tanggal 14 Maret 2017.

22 Wawancara dengan Anjar Arintaka Putra, selaku Kepala Bidang Penegakan Perda Satuan Polisi Pamong Praja (Satpol PP) Kabupaten Bantul, pada tanggal 15 Maret 2017.
} 
Kabupaten Bantul, ${ }^{23}$ diperoleh keterangan bahwa peredaran minuman beralkohol hampir merata di seluruh kecamatan se Kabupaten Bantul, tapi yang paling banyak ada di lokasi-lokasi wisata.

Sri Hartati, selaku Staf Penyidik PPNS Satuan Polisi Pamong Praja (Satpol PP) Kabupaten Bantul, ${ }^{24}$ juga menyatakan bahwa peredaran minuman beralkohol hampir merata di seluruh kecamatan se Kabupaten Bantul, tapi yang paling banyak ada di lokasi-lokasi wisata.

Berdasarkan hasil wawancara penulis dengan Teguh Nur Triono, selaku Kasi Pengkajian, Pengawasan dan Pengendalian Satuan Polisi Pamong Praja (Satpol PP) Kabupaten Bantul, ${ }^{25}$ diperoleh keterangan bahwa:

“...pemberian sanksi terhadap pelanggar Perda Nomor 2 Tahun 2012 yaitu ada sebagian pelanggar yang jera, akan tetapi ada sebagian yang masih mengulangi perbuatannya. Hal ini terjadi mungkin karena vonis/sanksi denda yang dikenakan tidak membuat efek jera dan keuntungan yang didapat apabila berjualah minuman beralkohol lebih besar dari denda yang dijatuhkan..."

Menurut Sismadi, selaku Kasi Penindakan Satuan Polisi Pamong Praja (Satpol PP) Kabupaten Bantul, ${ }^{26}$ diperoleh keterangan bahwa bahwa:

“...pemberian sanksi terhadap pelanggar Perda Nomor 2 Tahun 2012 yaitu sebagian melakukan penjualan lagi karena untungnya lebih besar. Apabila keputusan Pengadilan tinggi atau dilakukan hukuman kurungan bisa saja akan membuat jera..."

Sedangkan menurut Anjar Arintaka Putra, selaku Kepala Bidang Penegakan Perda Satuan Polisi Pamong Praja (Satpol PP) Kabupaten Bantul, ${ }^{27}$ diperoleh keterangan bahwa:

“...para penjual minuman beralkohol jelas-jelas telah melanggar Perda Nomor 2 Tahun 2012 dan harus dijatuhi sanksi, karena menjual miras adalah profesi dan keuntungan yang didapat dari menjual miras cukup besar. Sanksi yang biasanya dijatuhkan oleh pengadilan biasanya kurungan dan denda yang tinggi..."

Hal senada diungkapkan Andri Kusmiarno, selaku Staf Penyidik PPNS Satuan Polisi Pamong Praja (Satpol PP) Kabupaten Bantul, ${ }^{28}$ yang menyatakan bahwa:

${ }^{23}$ Wawancara dengan Andri Kusmiarno, selaku Staf Penyidik PPNS Satuan Polisi Pamong Praja (Satpol PP) Kabupaten Bantul, pada tanggal 15 Maret 2017.

${ }^{24}$ Wawancara dengan Sri Hartati, selaku Staf Penyidik PPNS Satuan Polisi Pamong Praja (Satpol PP) Kabupaten Bantul, pada tanggal 15 Maret 2017.

${ }^{25}$ Wawancara dengan Teguh Nur Triono, selaku Kasi Pengkajian, Pengawasan dan Pengendalian Satuan Polisi Pamong Praja (Satpol PP) Kabupaten Bantul, pada tanggal 14 Maret 2017.

${ }^{26}$ Wawancara dengan Sismadi, selaku Kasi Penindakan Satuan Polisi Pamong Praja (Satpol PP) Kabupaten Bantul, pada tanggal 14 Maret 2017.

27 Wawancara dengan Anjar Arintaka Putra, selaku Kepala Bidang Penegakan Perda Satuan Polisi Pamong Praja (Satpol PP) Kabupaten Bantul, pada tanggal 15 Maret 2017. 
“...para penjual minuman beralkohol jelas-jelas telah melanggar Perda Nomor 2 Tahun 2012 dan harus dijatuhi sanksi, karena menjual miras adalah profesi dan keuntungan yang didapat dari menjual miras cukup besar. Sanksi yang biasanya dijatuhkan oleh pengadilan biasanya kurungan dan denda yang tinggi..."

Sri Hartati, selaku Staf Penyidik PPNS Satuan Polisi Pamong Praja (Satpol PP) Kabupaten Bantul, ${ }^{29}$ juga menyatakan hal yang sama bahwa:

“...para penjual minuman beralkohol jelas-jelas telah melanggar Perda Nomor 2 Tahun 2012 dan harus dijatuhi sanksi, karena menjual miras adalah profesi dan keuntungan yang didapat dari menjual miras cukup besar. Sanksi yang biasanya dijatuhkan oleh pengadilan biasanya kurungan dan denda yang tinggi..."

Menurut Sri Widodo, penjual minuman keras di Kabupaten Bantul, walaupun sudah pernah tertangkap oleh Satpol PP namun dirinya tidak kapok untuk berjualan lagi dikarenakan biaya hukuman denda yang diberikan akan dibayar oleh si Produsen, sehingga penjual eceran tidak merugi. Selain itu juga, keuntungan penjualan miras lebih tinggi dari denda yang diberikan. ${ }^{30}$

Hal senada juga diungkapkan oleh Alip Yuliana dan Sugiyono yang juga berprofesi sebagai penjual minuman keras di kawasan wisata Pantai Parangkusumo yang menyatakan bahwa dia berjualan minuman keras sudah lama dan sudah beberapa kali ditangkap oleh petugas. Dia juga menyatakan bahwa keuntungan menjual minuman keras lumayan besar. ${ }^{31}$

Menurut Ismanto dan Gunawan, berjualan minuman keras cukup menguntungkan, dikarenakan apabila ada razia dari petugas, dia hanya minta bukti penyitaan kepada petugas dan nanti akan diberikan kepada distributor minuman keras tersebut yang nantinya minuman keras yang telah disita oleh petugas akan diganti oleh pihak distributor, sehingga dia tidak dirugikan atas penyitaan tersebut. ${ }^{32}$

Berkaitan dengan makna pelaksanaan peraturan daerah, bahwa hal tersebut sangat terkait erat dengan kewenangan desentralisasi. Bagaimana pemerintah (Bupati dan Organisasi Perangkat Daerah) sebagai eksekutif di daerah dapat menjalankan fungsi pelaksanaan peraturan daerah. Pengertian desentralisasi menimbulkan konsekuensi penyerahan wewenang dari pemerintah pusat ke pemerintah daerah yang salah satunya adalah penyerahan

\footnotetext{
${ }^{28}$ Wawancara dengan Andri Kusmiarno, selaku Staf Penyidik PPNS Satuan Polisi Pamong Praja (Satpol PP) Kabupaten Bantul, pada tanggal 15 Maret 2017.

${ }^{29}$ Wawancara dengan Sri Hartati, selaku Staf Penyidik PPNS Satuan Polisi Pamong Praja (Satpol PP) Kabupaten Bantul, pada tanggal 15 Maret 2017.

${ }^{30}$ Wawancara dengan Sri Widodo, selaku penjual minuman keras di Kabupaten Bantul, pada tanggal 17 Maret 2017.

31 Wawancara dengan Alip Yuliana dan Sugiyono, selaku penjual minuman keras di Kabupaten Bantul, pada tanggal 17 Maret 2017.

32 Wawancara dengan Ismanto dan Gunawan, selaku penjual minuman keras di Kabupaten Bantul, pada tanggal 17 Maret 2017.
} 
kewenangan pembentukan peraturan daerah dan kewenangan untuk melaksanakannya yang didasarkannya pada konsep pemisahan kekuasaan tersebut di atas tadi.

Peraturan Daerah merupakan salah satu dari jenis peraturan perundangundangan yang berlaku dalam sistem ketatanegaraan Indonesia dewasa ini. Undang-Undang Nomor 12 Tahun 2011 tentang Pembentukan Peraturan Perundang-undangan, menjadi landasan hukum untuk penyusunan peraturan perundang-undangan termasuk juga peraturan lokal tadi yaitu peraturan daerah yang berlaku mengikat bagi daerah tempat peraturan daerah itu dibentuk. Peraturan Daerah merupakan produk hukum daerah yang ditetapkan oleh kepala daerah atas persetujuan Dewan Perwakilan Rakyat Daerah, dan dalam pelaksanaannya berlaku secara lokal, sehingga kekuatan mengikatnya hanya pada daerah dibentuk. Peraturan Daerah tetap mengacu pada peraturan hukum lebih tinggi di atasnya, sehingga tidak serta merta akan mengesampingkan aturan-aturan yang lebih tinggi.

Prinsip peraturan daerah adalah untuk melaksanakan peraturan yang lebih tinggi diatasnya maka tidak boleh bertentangan dengan peraturan yang lebih tinggi tersebut. Oleh karena itu daya ikat dari Peraturan Daerah adalah hanya mengikat bagi setiap aspek-aspek kepentingan daerah, namun tidak berarti dengan berlaku mengikat secara lokal tersebut, sehingga pemerintah daerah menganggap bahwa pengawasan pemerintah terhadap peraturan daerah tidak ada. Justru kewenangan pembentukan peraturan daerah diberikan kepada daerah untuk melakukannya dengan tetap mendapat pengawasan dan pembinaan hukum oleh pemerintah melalui institusi pemerintah yang berkompeten, yaitu Kementerian Hukum dan Hak Asasi Manusia Republik Indonesia. Kewenangan pembentukan peraturan daerah (perda) tersebut, merupakan wujud nyata pelaksanaan hak otonomi yang dimiliki oleh suatu daerah dan sebaliknya peraturan daerah merupakan salah satu sarana penyelenggaraan otonomi daerah.

Peraturan daerah ditetapkan oleh Kepala Daerah setelah mendapat persetujuan bersama dengan DPRD, untuk penyelenggaraan otonomi yang dimiliki oleh daerah provinsi/kabupaten/kota. Peraturan daerah pada dasarnya merupakan penjabaran lebih lanjut dari peraturan perundang-undangan yang lebih tinggi sebagaimana dijelaskan di atas, dengan memperhatikan ciri khas masing-masing daerah. Peraturan daerah yang dibuat oleh suatu daerah, baru mempunyai kekuatan mengikat setelah diundangkan dengan dimuat dalam lembaran daerah, namun dalam asas hukum pemberlakuannya tidak boleh bertentangan dengan Peraturan Perundang-undangan yang lebih tinggi dan atau menyangkut kepentingan umum. 


\section{Eksistensi Peraturan Daerah Tentang Minuman Beralkohol di Kabupaten Bantul Dalam Menekan Penjualan dan Perdaran Miras}

Tugas pokok pemerintah adalah menciptakan kebijakan melalui berbagai kebijakan publik. Kebijakan akan tercapai jika kebijakan yang dibuat dapat terimplementasikan atau dapat dilaksanakan secara baik. Keberhasilan implementasi suatu kebijakan ditentukan oleh banyak variabel atau faktor, baik menyangkut isi kebijakan yang diimplementasikan, pelaksanaan kebijakan, maupun lingkungan di mana kebijakan tersebut diimplementasikan (kelompok sasaran).

Menurut Winarno, implementasi dipandang secara luas mempunyai makna pelaksanaan undang-undang dimana berbagai aktor, organisasi, prosedur dan teknik bekerja bersama-sama menjalankan kebijakan dalam upaya untuk meraih tujuan-tujuan kebijakan. Implementasi pada sisi yang lain merupakan fenomena yang kompleks yang mungkin dapat dipahami sebagai suatu proses, suatu keluaran (output) maupun sebagai suatu dampak (outcome). ${ }^{33}$

Selanjutnya, Widodo menyatakan bahwa implementasi kebijakan publik merupakan salah satu tahapan dari proses kebijakan publik (public policy proces) sekaligus studi yang sangat crusial. Bersifat crusial karena bagaimanapun baiknya suatu kebijakan, kalau tidak dipersiapkan dan direncanakan secara baik dalam implementasinya, maka tujuan kebijakan tidak akan bisa diwujudkan, begitu pula sebaliknya. Dengan demikian, jika menghendaki tujuan kebijakan dapat dicapai dengan baik, maka bukan saja pada tahap implementasi yang harus dipersiapkan dan direncanakan dengan baik, tetapi juga pada tahap perumusan atau pembuatan kebijakan juga telah diantisipasi untuk dapat diimplementasikan. ${ }^{34}$

Pengedaran dan penjualan minuman beralkohol merupakan permasalahan sosial yang perlu mendapatkan perhatian serius semua pihak, baik aparat pemerintah, tokoh masyarakat maupun masyarakat pada umumnya, karena bertentangan dengan nilai-nilai sosial, keagamaan, ketertiban dan seluruh aspek perikehidupan masyarakat.

Untuk meningkatkan pelayanan kepada masyarakat di bidang perizinan, telah dibentuk perangkat daerah yang mempunyai tugas melaksanakan urusan rumah tangga pemerintahan daerah dan tugas pembantuan di bidang perizinan. Untuk memberikan kepastian hukum bagi perangkat daerah yang melaksanakan urusan rumah tangga pemerintahan daerah dan tugas pembantuan di bidang perizinan, maka beberapa Peraturan Daerah yang mengatur perizinan perlu dilakukan penyesuaian, sehingga mendukung tugas, fungsi dan wewenang perangkat daerah dimaksud tanpa meninggalkan tugas pengawasan dan

${ }^{33}$ Budi Winarno, Kebijakan Publik Teori dan Proses, (Jakarta: PT Buku Kita, 2008), h. 144.

34 Joko Widodo, Analisis Kebijakan Publik, (Malang: Bayumedi, 2007), h. 85. 
pengendalian bagi perangkat daerah yang melaksanakan urusan terkait izin yang bersangkutan. Berdasarkan hal tersebut maka Pemerintah Kabupaten Bantul mengeluarkan Peraturan Daerah Nomor 2 Tahun 2012 tentang Pengawasan, Pengendalian, Pengedaran dan Pelarangan Penjualan Minuman Beralkohol di Kabupaten Bantul.

Salah satu tahap implementasi adalah tahap pelaksanaan. Pelaksanaan di sini maksudnya adalah tahap pemberian izin dan pengawasan terhadap pengedaran dan penjualan minuman beralkohol dan dilanjutkan dengan penegakan hukum bagi yang melanggar Peraturan Daerah Nomor 2 Tahun 2012 tentang Pengawasan, Pengendalian, Pengedaran dan Pelarangan Penjualan Minuman Beralkohol di Kabupaten Bantul.

Berdasarkan ketentuan Pasal 3 Peraturan Daerah Nomor 2 Tahun 2012 tentang Pengawasan, Pengendalian, Pengedaran dan Pelarangan Penjualan Minuman Beralkohol di Kabupaten Bantul dinyatakan bahwa:

Minuman beralkohol dikelompokan dalam golongan-golongan sebagai berikut:

a. minuman beralkohol golongan A adalah minuman beralkohol dengan kadar ethanol $(\mathrm{C} 2 \mathrm{H} 5 \mathrm{OH})$ di atas $0 \%$ (nol perseratus) sampai dengan $5 \%$ (lima perseratus);

b. minuman beralkohol golongan $\mathrm{B}$ adalah minuman beralkohol dengan kadar ethanol (C2H5OH) lebih dari 5\% (lima perseratus) sampai dengan $20 \%$ (dua puluh perseratus); dan

c. minuman beralkohol golongan $\mathrm{C}$ adalah minuman beralkohol dengan kadar ethanol $(\mathrm{C} 2 \mathrm{H} 5 \mathrm{OH})$ lebih dari $20 \%$ (dua puluh perseratus) sampai dengan 55\% (lima puluh lima perseratus)

Berdasarkan ketentuan Pasal 5 Peraturan Daerah Nomor 2 Tahun 2012 tentang Pengawasan, Pengendalian, Pengedaran dan Pelarangan Penjualan Minuman Beralkohol di Kabupaten Bantul dinyatakan bahwa:

Pengedaran minuman beralkohol golongan B dan/atau golongan C di Daerah hanya dapat dilakukan oleh perusahaan yang ditunjuk sesuai peraturan perundang-undangan yang berlaku.

Mengenai tempat penjualan minuman beralkohol, diatur dalam Pasal 6 Peraturan Daerah Nomor 2 Tahun 2012 tentang Pengawasan, Pengendalian, Pengedaran dan Pelarangan Penjualan Minuman Beralkohol di Kabupaten Bantul, yaitu:

(1)Tempat Penjualan Minuman Beralkohol di Daerah hanya dapat diselenggarakan pada:

a. Hotel Berbintang 3 (tiga), Hotel Berbintang 4 (empat), dan Hotel Berbintang 5 (lima); 
b. Restoran dengan Tanda Talam Kencana dan Talam Selaka; dan

c. Bar termasuk pub dan klab malam.

(2)Tempat-tempat sebagaimana dimaksud pada ayat (1) berfungsi sebagai penjual langsung minuman beralkohol golongan $\mathrm{B}$ dan golongan $\mathrm{C}$ untuk diminum langsung.

(3) Selain tempat-tempat sebagaimana dimaksud pada ayat (1) dilarang sebagai tempat penjualan langsung minuman beralkohol di Daerah.

(4) Minuman beralkohol golongan A dapat dijual langsung di tempat sebagaimana dimaksud pada ayat (1) untuk diminum langsung.

Akan tetapi dalam kenyataan yang terjadi di Kabupaten Bantul, banyak tempat-tempat hiburan khususnya di kawasan wisata pantai banyak yang menjual minuman beralkohol tanpa izin. Hal tersebut senada dengan apa yang diungkapkan oleh Sismadi, selaku Kasi Penindakan Satuan Polisi Pamong Praja (Satpol PP) Kabupaten Bantul, ${ }^{35}$ yang menyatakan bahwa:

“...di Kabupaten Bantul yang boleh atau diijinkan menjual minuman beralkohol hanya di Hotel Berbintang 3, 4 dan 5. Jadi penjual yang bukan pemilik hotel tadi sudah pasti melanggar Perda Nomor 2 Tahun 2012..."

Berdasarkan ketentuan Pasal 8 Peraturan Daerah Nomor 2 Tahun 2012 tentang Pengawasan, Pengendalian, Pengedaran dan Pelarangan Penjualan Minuman Beralkohol di Kabupaten Bantul, dinyatakan bahwa:

Setiap perusahaan yang akan melakukan kegiatan usaha penjualan minuman beralkohol golongan B dan/atau golongan $\mathrm{C}$ wajib memiliki Izin Tempat Penjualan Minuman Beralkohol dan SIUP MB dari Bupati atau pejabat yang ditunjuk.

Menurut Pasal 11 Peraturan Daerah Nomor 2 Tahun 2012 tentang Pengawasan, Pengendalian, Pengedaran dan Pelarangan Penjualan Minuman Beralkohol di Kabupaten Bantul, dinyatakan bahwa:

(1) Permohonan Izin Tempat Penjualan Minuman Beralkohol diajukan kepada Bupati atau pejabat yang ditunjuk dengan mengisi formulir yang disediakan dan dilampiri persyaratan sebagai berikut:

a. Izin Tempat Penjualan Minuman Beralkohol untuk Hotel Berbintang 3 (tiga), Hotel Berbintang 4 (empat), atau Hotel Berbintang 5 (lima), terdiri atas:

1. foto copy KTP yang masih berlaku dari pemohon;

2. pas foto pemohon berwarna ukuran $3 \times 4$ sebanyak 3 (tiga) lembar;

${ }^{35}$ Wawancara dengan Sismadi, selaku Kasi Penindakan Satuan Polisi Pamong Praja (Satpol PP) Kabupaten Bantul, pada tanggal 14 Maret 2017. 
3. foto copy Izin Gangguan yang mencantumkan untuk kegiatan usaha perdagangan minuman beralkohol;

4. foto copy sertifikat hotel berbintang;

5. foto copy surat penunjukan sebagai penjual langsung dari produsen atau Importir Terdaftar Minuman Beralkohol (ITMB) atau distributor atau sub distributor atau kombinasi keempatnya;

6. foto copy surat izin usaha bidang kepariwisataan;

7. denah lokasi penyimpanan dan penyajian minuman beralkohol;

8. daftar minuman beralkohol yang akan dijual; dan

9. surat kuasa bermeterai cukup apabila permohonan diwakilkan.

b. Izin Tempat Penjualan Minuman Beralkohol untuk Restoran dengan Tanda Talam Kencana dan Talam Selaka, terdiri atas:

1. foto copy KTP yang masih berlaku dari pemohon;

2. pas foto pemohon berwarna ukuran $3 \times 4$ sebanyak 3 (tiga) lembar;

3. foto copy Izin Gangguan yang mencantumkan untuk kegiatan usaha perdagangan minuman beralkohol;

4. foto copy sertifikat klasifikasi restoran;

5. foto copy surat penunjukan sebagai penjual langsung dari produsen atau Importir Terdaftar Minuman Beralkohol (ITMB) atau distributor atau sub distributor atau kombinasi keempatnya;

6. foto copy surat izin usaha bidang kepariwisataan;

7. denah lokasi penyimpanan dan penyajian minuman beralkohol;

8. daftar minuman beralkohol yang akan dijual; dan

9. surat kuasa bermeterai cukup apabila permohonan diwakilkan.

c. Izin Tempat Penjualan Minuman Beralkohol untuk Bar, pub dan klab malam, terdiri atas:

1. foto copy KTP yang masih berlaku dari pemohon;

2. pas foto pemohon berwarna ukuran $3 \times 4$ sebanyak 3 (tiga) lembar;

3. foto copy Izin Gangguan yang mencantumkan untuk kegiatan usaha perdagangan minuman beralkohol;

4. foto copy surat izin usaha bidang kepariwisataan; 
5. foto copy surat penunjukan sebagai penjual langsung dari produsen atau Importir Terdaftar Minuman Beralkohol (ITMB) atau distributor atau sub distributor atau kombinasi keempatnya;

6. denah lokasi penyimpanan dan penyajian minuman beralkohol;

7. daftar minuman beralkohol yang akan dijual; dan

8. surat kuasa bermeterai cukup apabila permohonan diwakilkan.

(2)Bupati atau pejabat yang ditunjuk melakukan pencermatan kebenaran dokumen persyaratan dan peninjauan lokasi sebelum diterbitkannya Izin Tempat Penjualan Minuman Beralkohol.

(3) Penerbitan Izin Tempat Penjualan Minuman Beralkohol diterbitkan paling lama 12 (dua belas) hari kerja terhitung sejak diterimanya berkas permohonan dengan lengkap dan benar.

(4)Dalam hal berkas permohonan izin tidak memenuhi syarat dan ditolak, maka surat pengembalian berkas permohonan diterbitkan paling lama 12 (dua belas) hari kerja sejak diterimanya berkas permohonan.

(5) Penyerahan izin dilakukan setelah pemohon membayar retribusi Izin Tempat Penjualan Minuman Beralkohol.

Dikarenakan banyaknya persyaratan yang harus dipenuhi dalam mengurus izin tempat penjualan minuman beralkohol menyebabkan banyak penjual minuman beralkohol yang malas atau enggan untuk mengurus izin tersebut. Hal tersebut senada dengan yang diungkapkan oleh Anjar Arintaka Putra, selaku Kepala Bidang Penegakan Perda Satuan Polisi Pamong Praja (Satpol PP) Kabupaten Bantul, ${ }^{36}$ yang menyatakan bahwa:

“...hal yang menyebabkan masih banyak terjadinya pelanggaran Perda Nomor 2 Tahun 2012 adalah karena para penjual minuman keras ini lebih banyak yang enggan mengurus ijin, sehingga minuman dijual secara bebas, berakibat orang banyak yang mengkonsumsi..."

Hal senada diungkapkan oleh Andri Kusmiarno, selaku Staf Penyidik PPNS Satuan Polisi Pamong Praja (Satpol PP) Kabupaten Bantul, ${ }^{37}$ yang menyatakan bahwa:

“...hal yang menyebabkan masih banyak terjadinya pelanggaran Perda Nomor 2 Tahun 2012 adalah karena para penjual minuman keras ini lebih banyak yang enggan mengurus ijin, sehingga minuman dijual secara bebas, berakibat orang banyak yang mengkonsumsi..."

\footnotetext{
${ }^{36}$ Wawancara dengan Anjar Arintaka Putra, selaku Kepala Bidang Penegakan Perda Satuan Polisi Pamong Praja (Satpol PP) Kabupaten Bantul, pada tanggal 15 Maret 2017.

${ }^{37}$ Wawancara dengan Andri Kusmiarno, selaku Staf Penyidik PPNS Satuan Polisi Pamong Praja (Satpol PP) Kabupaten Bantul, pada tanggal 15 Maret 2017.
} 
Hal senada juga diungkapkan oleh Sri Hartati, selaku Staf Penyidik PPNS Satuan Polisi Pamong Praja (Satpol PP) Kabupaten Bantul, ${ }^{38}$ diperoleh keterangan bahwa:

“...hal yang menyebabkan masih banyak terjadinya pelanggaran Perda Nomor 2 Tahun 2012 adalah kurangnya kesadaran hukum dan peran serta masyarakat yaitu kurangnya kesadaran masyarakat akan bahayanya minuman beralkohol..."

Menurut Pasal 21 Peraturan Daerah Nomor 2 Tahun 2012 tentang Pengawasan, Pengendalian, Pengedaran dan Pelarangan Penjualan Minuman Beralkohol di Kabupaten Bantul, dinyatakan bahwa:

(1)Setiap orang pribadi atau perusahaan dilarang memproduksi, mengkonsumsi, menyimpan, menjual dan/atau mengedarkan minuman beralkohol yang tidak termasuk ke dalam golongan A, golongan B, golongan $\mathrm{C}$ termasuk di dalamnya minuman hasil oplosan atau enceran, dan jenis minuman beralkohol lainnya.

(2) Penjual langsung minuman beralkohol golongan B yang mengandung rempahrempah, jamu dan sejenisnya dilarang menjual minuman beralkohol dengan kadar ethanol di atas 15\% (lima belas per seratus) dan golongan $\mathrm{C}$.

(3) Penjual langsung minuman beralkohol dilarang menjual minuman beralkohol selain yang berasal dari 5 (lima) produsen atau Importir Terdaftar Minuman Beralkohol (ITMB) atau distributor atau sub distributor atau kombinasi keempatnya yang menunjuknya.

(4)Setiap orang pribadi atau perusahaan dilarang menjual secara eceran dalam kemasan minuman beralkohol golongan $\mathrm{A}$, golongan $\mathrm{B}$ dan golongan $\mathrm{C}$ dan/atau menjual langsung untuk diminum di tempat, di lokasi sebagai berikut:

a. gelanggang remaja, kaki lima, terminal, stasiun, kios-kios kecil, penginapan remaja, dan bumi perkemahan;

b. tempat yang berdekatan tempat ibadah, sekolah, rumah sakit, dan permukiman; dan

c. tempat tertentu lainnya yang ditetapkan oleh Bupati.

(5)Setiap orang pribadi atau perusahaan yang tidak memiliki Izin Tempat Penjualan Minuman Beralkohol, SIUP MB dan/atau SIUP dilarang melakukan pengedaran, penjualan dan penyimpanan minuman beralkohol.

38 Wawancara dengan Sri Hartati, selaku Staf Penyidik PPNS Satuan Polisi Pamong Praja (Satpol PP) Kabupaten Bantul, pada tanggal 15 Maret 2017. 
Berdasarkan ketentuan pasal tersebut, Peraturan Daerah Nomor 2 Tahun 2012 tentang Pengawasan, Pengendalian, Pengedaran dan Pelarangan Penjualan Minuman Beralkohol di Kabupaten Bantul sudah cukup baik dalam mengakomodir peredaran dan pelarangan penjualan minuman beralkohol. Hal tersebut senada dengan ungkapan Teguh Nur Triono, selaku Kasi Pengkajian, Pengawasan dan Pengendalian Satuan Polisi Pamong Praja (Satpol PP) Kabupaten Bantul, ${ }^{39}$ diperoleh keterangan bahwa:

“...Perda Nomor 2 Tahun 2012 sudah cukup baik, karena dalam Perda Nomor 2 Tahun 2012 sudah merupakan perubahan dari Perda Nomor 6 Tahun 2007 yang sudah mengakomodir adanya pelanggaran minuman beralkohol oplosan, sehingga dalam pengedaran dan penjualan minuman beralkohol sudah berkurang dan sudah banyak ditekan dalam jumlah maupun pelanggarannya. Perda Nomor 2 Tahun 2012 sudah baik, hal ini berarti bahwa Perda Kabupaten Bantul Nomor 2 Tahun 2012 tentang Pengawasan, Pengendalian, Pengedaran dan Pelarangan Penjualan Minuman Beralkohol di Kabupaten Bantul merupakan sebuah kebijakan/regulasi yang dapat menanggulangi/ membatasi peredaran dan penjualan minuman beralkohol di Kabupaten Bantul..."

Menurut Sismadi, selaku Kasi Penindakan Satuan Polisi Pamong Praja (Satpol PP) Kabupaten Bantul, ${ }^{40}$ diperoleh keterangan bahwa: “...dalam Perda Nomor 2 Tahun 2012 sepertinya sudah cukup baik, hanya karena kurang personil menjadi kendala untuk pengawasan dan Perda Nomor 2 Tahun 2012 tidak perlu dilakukan revisi..."

Berdasarkan hasil wawancara penulis dengan Anjar Arintaka Putra, selaku Kepala Bidang Penegakan Perda Satuan Polisi Pamong Praja (Satpol PP) Kabupaten Bantul, ${ }^{41}$ diperoleh keterangan bahwa Perda Nomor 2 Tahun 2012 sudah cukup bagus, mungkin kelemahannya hanya perlu diperbesar/diperberat sanksi/dendanya. Hal senada diungkapkan oleh Andri Kusmiarno, selaku Staf Penyidik PPNS Satuan Polisi Pamong Praja (Satpol PP) Kabupaten Bantul, ${ }^{42}$ diperoleh keterangan bahwa: “...Perda Nomor 2 Tahun 2012 sudah cukup bagus, mungkin kelemahannya hanya perlu diperbesar/diperberat sanksi pidana maupun dendanya..."

${ }^{39}$ Wawancara dengan Teguh Nur Triono, selaku Kasi Pengkajian, Pengawasan dan Pengendalian Satuan Polisi Pamong Praja (Satpol PP) Kabupaten Bantul, pada tanggal 14 Maret 2017.

${ }^{40}$ Wawancara dengan Sismadi, selaku Kasi Penindakan Satuan Polisi Pamong Praja (Satpol PP) Kabupaten Bantul, pada tanggal 14 Maret 2017.

${ }^{41}$ Wawancara dengan Anjar Arintaka Putra, selaku Kepala Bidang Penegakan Perda Satuan Polisi Pamong Praja (Satpol PP) Kabupaten Bantul, pada tanggal 15 Maret 2017.

42 Wawancara dengan Andri Kusmiarno, selaku Staf Penyidik PPNS Satuan Polisi Pamong Praja (Satpol PP) Kabupaten Bantul, pada tanggal 15 Maret 2017. 
Hal senada juga diungkapkan oleh Sri Hartati, selaku Staf Penyidik PPNS Satuan Polisi Pamong Praja (Satpol PP) Kabupaten Bantul, ${ }^{43}$ diperoleh keterangan bahwa Perda Nomor 2 Tahun 2012 tidak ada kelemahannya sehingga tidak perlu diadakan revisi terhadap Perda tersebut.

Berdasarkan hasil wawancara penulis dengan Teguh Nur Triono, selaku Kasi Pengkajian, Pengawasan dan Pengendalian Satuan Polisi Pamong Praja (Satpol PP) Kabupaten Bantul, ${ }^{44}$ diperoleh keterangan bahwa penggunaan minuman beralkohol jelas-jelas bertentangan dengan budaya, adat istiadat dan norma-norma yang berlaku di masyarakat Bantul. Menurut Sismadi, selaku Kasi Penindakan Satuan Polisi Pamong Praja (Satpol PP) Kabupaten Bantul, ${ }^{45}$ diperoleh keterangan bahwa: “...bagi masyarakat yang sering menggunakan minuman beralkohol masih cukup banyak bahkan juga mengkonsumsi minuman jenis lainnya (ciu dan oplosan)."

Berdasarkan hasil wawancara penulis dengan Anjar Arintaka Putra, selaku Kepala Bidang Penegakan Perda Satuan Polisi Pamong Praja (Satpol PP) Kabupaten Bantul, ${ }^{46}$ diperoleh keterangan bahwa: “...budaya masyarakat Bantul, khusus yang sering menggunakan minuman beralkohol masih banyak yang menggunakan minuman oplosan..."

Hal senada diungkapkan oleh Andri Kusmiarno, selaku Staf Penyidik PPNS Satuan Polisi Pamong Praja (Satpol PP) Kabupaten Bantul, ${ }^{47}$ diperoleh keterangan bahwa: “...budaya masyarakat Bantul, khususnya yang sering menggunakan minuman beralkohol masih banyak yang menggunakan minuman oplosan..."

Menurut Sri Hartati, selaku Staf Penyidik PPNS Satuan Polisi Pamong Praja (Satpol PP) Kabupaten Bantul, ${ }^{48}$ diperoleh keterangan bahwa hanya sebagian kecil masyarakat Bantul yang masih diam-diam dalam mengkonsumsi/menjual minuman beralkohol.

${ }^{43}$ Wawancara dengan Sri Hartati, selaku Staf Penyidik PPNS Satuan Polisi Pamong Praja (Satpol PP) Kabupaten Bantul, pada tanggal 15 Maret 2017.

${ }^{44}$ Wawancara dengan Teguh Nur Triono, selaku Kasi Pengkajian, Pengawasan dan Pengendalian Satuan Polisi Pamong Praja (Satpol PP) Kabupaten Bantul, pada tanggal 14 Maret 2017.

${ }^{45}$ Wawancara dengan Sismadi, selaku Kasi Penindakan Satuan Polisi Pamong Praja (Satpol PP) Kabupaten Bantul, pada tanggal 14 Maret 2017.

${ }^{46}$ Wawancara dengan Anjar Arintaka Putra, selaku Kepala Bidang Penegakan Perda Satuan Polisi Pamong Praja (Satpol PP) Kabupaten Bantul, pada tanggal 15 Maret 2017.

${ }^{47}$ Wawancara dengan Andri Kusmiarno, selaku Staf Penyidik PPNS Satuan Polisi Pamong Praja (Satpol PP) Kabupaten Bantul, pada tanggal 15 Maret 2017.

48 Wawancara dengan Sri Hartati, selaku Staf Penyidik PPNS Satuan Polisi Pamong Praja (Satpol PP) Kabupaten Bantul, pada tanggal 15 Maret 2017. 
Berdasarkan ketentuan Pasal 25 Peraturan Daerah Nomor 2 Tahun 2012 tentang Pengawasan, Pengendalian, Pengedaran dan Pelarangan Penjualan Minuman Beralkohol di Kabupaten Bantul, dinyatakan bahwa

Pengawasan dan pengendalian dilakukan oleh Bupati atau pejabat yang ditunjuk terhadap:

a. penjual langsung minuman beralkohol golongan $\mathrm{A}$, golongan $\mathrm{B}$, dan golongan C;

b. perizinan, pelaksanaan pengedaran dan penjualan minuman beralkohol golongan $\mathrm{A}$, golongan $\mathrm{B}$, dan golongan $\mathrm{C}$; dan

c. tempat/lokasi penyimpanan, pengedaran dan penjualan minuman beralkohol.

Sedangkan menurut Pasal 26 Peraturan Daerah Nomor 2 Tahun 2012 tentang Pengawasan, Pengendalian, Pengedaran dan Pelarangan Penjualan Minuman Beralkohol di Kabupaten Bantul, dinyatakan bahwa:

(1) Dalam rangka melaksanakan pengawasan dan pengendalian, pengedaran dan penjualan minuman beralkohol, Bupati atau pejabat yang ditunjuk melakukan koordinasi secara berkala dengan instansi terkait dan tokoh masyarakat.

(2) Koordinasi sebagaimana dimaksud pada ayat (1) dapat dilaksanakan sewaktuwaktu apabila diperlukan.

(3) Ketentuan mengenai koordinasi pengawasan dan pengendalian akan diatur lebih lanjut dengan Peraturan Bupati.

Berdasarkan hasil wawancara penulis dengan Teguh Nur Triono, selaku Kasi Pengkajian, Pengawasan dan Pengendalian Satuan Polisi Pamong Praja (Satpol PP) Kabupaten Bantul, ${ }^{49}$

“...mengenai alasan terjadi pelanggaran Perda yaitu bahwa di Kabupaten Bantul telah berlaku Perda Kabupaten Bantul Nomor 2 Tahun 2012 dan/atau perda-perda yang lain. Hal ini dikarenakan kegiatan sosialisasi terhadap perda-perda yang ada khususnya Perda Nomor 2 Tahun 2012 belum sampai menyentuh ke warga masyarakat. Dimungkinkan pelaksanaan sosialisasi dilaksanakan hanya terhadap tokoh-tokoh masyarakat, stakeholder dan lembaga/badan terkait..."

Berdasarkan hasil wawancara penulis dengan Teguh Nur Triono, selaku Kasi Pengkajian, Pengawasan dan Pengendalian Satuan Polisi Pamong Praja (Satpol PP) Kabupaten Bantul, ${ }^{50}$ diperoleh keterangan bahwa:

“...sosialisasi Perda Kabupaten Bantul Nomor 2 Tahun 2012 dilaksanakan melalui berbagai media, yaitu antara lain media elektronik (media radio), media cetak

${ }^{49}$ Wawancara dengan Teguh Nur Triono, selaku Kasi Pengkajian, Pengawasan dan Pengendalian Satuan Polisi Pamong Praja (Satpol PP) Kabupaten Bantul, pada tanggal 14 Maret 2017.

${ }^{50}$ Wawancara dengan Teguh Nur Triono, selaku Kasi Pengkajian, Pengawasan dan Pengendalian Satuan Polisi Pamong Praja (Satpol PP) Kabupaten Bantul, pada tanggal 14 Maret 2017. 
(surat kabar lokal setempat), media tatap muka (penyuluhan, rata-rata dan lainlain) serta media lain (brosur, leaflet dan lain-lain)..."

Menurut Sismadi, selaku Kasi Penindakan Satuan Polisi Pamong Praja (Satpol PP) Kabupaten Bantul, ${ }^{51}$ diperoleh keterangan bahwa: “...sosialisasi dilakukan di seluruh wilayah Kabupaten Bantul terutama di daerah rawan pengguna minuman beralkohol, bahkan juga dilakukan di sekolah-sekolah yang dianggap rawan pengguna minuman beralkohol..."

Berdasarkan hasil wawancara penulis dengan Anjar Arintaka Putra, selaku Kepala Bidang Penegakan Perda Satuan Polisi Pamong Praja (Satpol PP) Kabupaten Bantul, ${ }^{52}$ diperoleh keterangan bahwa:

“...pelaksanaan sosialisasi oleh Satpol PP dilakukan 4 kali setahun. Selain itu sering diminta menjadi narasumber apabila ada kelompok masyarakat yang mengadakan kegiatan penyuluhan dan pembinaan terkait dengan Perda Nomor 2 Tahun 2012 tersebut..."

Hal senada diungkapkan Andri Kusmiarno, selaku Staf Penyidik PPNS Satuan Polisi Pamong Praja (Satpol PP) Kabupaten Bantul, ${ }^{53}$ yang menyatakan bahwa:

“...pelaksanaan sosialisasi oleh Satpol PP dilakukan 4 kali setahun. Selain itu sering diminta menjadi narasumber apabila ada kelompok masyarakat yang mengadakan kegiatan penyuluhan dan pembinaan terkait dengan Perda Nomor 2 Tahun 2012 tersebut..."

Berdasarkan hasil wawancara penulis dengan Sri Hartati, selaku Staf Penyidik PPNS Satuan Polisi Pamong Praja (Satpol PP) Kabupaten Bantul,54 diperoleh keterangan bahwa sering dilakukan sosialisasi di desa-desa dan disekolah-sekolah.

Berdasarkan hasil wawancara penulis dengan Teguh Nur Triono, selaku Kasi Pengkajian, Pengawasan dan Pengendalian Satuan Polisi Pamong Praja (Satpol PP) Kabupaten Bantul, ${ }^{55}$ diperoleh keterangan bahwa: “...implementasi Perda Nomor 2 Tahun 2012 di Kabupaten Bantul berjalan sesuai harapan yaitu dapat mengurangi, menekan, dan membatasi peredaran minuman beralkohol di Kabupaten Bantul..."

${ }^{51}$ Wawancara dengan Sismadi, selaku Kasi Penindakan Satuan Polisi Pamong Praja (Satpol PP) Kabupaten Bantul, pada tanggal 14 Maret 2017.

${ }^{52}$ Wawancara dengan Anjar Arintaka Putra, selaku Kepala Bidang Penegakan Perda Satuan Polisi Pamong Praja (Satpol PP) Kabupaten Bantul, pada tanggal 15 Maret 2017.

${ }^{53}$ Wawancara dengan Andri Kusmiarno, selaku Staf Penyidik PPNS Satuan Polisi Pamong Praja (Satpol PP) Kabupaten Bantul, pada tanggal 15 Maret 2017.

${ }^{54}$ Wawancara dengan Sri Hartati, selaku Staf Penyidik PPNS Satuan Polisi Pamong Praja (Satpol PP) Kabupaten Bantul, pada tanggal 15 Maret 2017.

55 Wawancara dengan Teguh Nur Triono, selaku Kasi Pengkajian, Pengawasan dan Pengendalian Satuan Polisi Pamong Praja (Satpol PP) Kabupaten Bantul, pada tanggal 14 Maret 2017. 
Menurut Sismadi, selaku Kasi Penindakan Satuan Polisi Pamong Praja (Satpol PP) Kabupaten Bantul, ${ }^{56}$ diperoleh keterangan bahwa: “...implementasi Perda Nomor 2 Tahun 2012 sudah cukup baik, Satpol PP Kabupaten Bantul tidak menemukan kesulitan dalam melakukan penegakan sampai ke raha yustisi..."

Berdasarkan hasil wawancara penulis dengan Anjar Arintaka Putra, selaku Kepala Bidang Penegakan Perda Satuan Polisi Pamong Praja (Satpol PP) Kabupaten Bantul, ${ }^{57}$ diperoleh keterangan bahwa implementasi Perda Nomor 2 Tahun 2012, menurut ketugasan Satpol PP sudah cukup lancar dan bagus, terutama dalam penegakannya. Hal senada diungkapkan oleh Andri Kusmiarno, selaku Staf Penyidik PPNS Satuan Polisi Pamong Praja (Satpol PP) Kabupaten Bantul, ${ }^{58}$ diperoleh keterangan bahwa implementasi Perda Nomor 2 Tahun 2012, sudah cukup baik dan bagus, terutama dalam penegakannya.

Berdasarkan hasil wawancara penulis dengan Sri Hartati, selaku Staf Penyidik PPNS Satuan Polisi Pamong Praja (Satpol PP) Kabupaten Bantul, ${ }^{59}$ diperoleh keterangan bahwa: “...implementasi Perda Nomor 2 Tahun 2012 sudah berjalan dengan sangat baik terbukti banyak pelanggar yang telah diajukan ke sidang Pengadilan Negeri Bantul dan diputus oleh hakim..."

Akan tetapi walaupun di Kabupaten Bantul sudah ada Peraturan Daerah Kabupaten Bantul Nomor 2 Tahun 2012 tentang Pengawasan, Pengendalian, Pengedaran dan Pelarangan Penjualan Minuman Beralkohol di Kabupaten Bantul, penjualan dan peredaran minuman keras masih banyak terjadi di Kabupaten Bantul. Hal ini dikarenakan sanksi yang diberikan kepada pelaku penjualan dan peredaran minuman keras terlalu ringan sehingga tidak menjadikan efek jera bagi para pelakunya. Guna mengatasi hal tersebut, hendaknya dalam Peraturan Daerah Kabupaten Bantul Nomor 2 Tahun 2012 tentang Pengawasan, Pengendalian, Pengedaran dan Pelarangan Penjualan Minuman Beralkohol di Kabupaten Bantul dilakukan revisi dengan memberikan sanksi yang berat kepada para pelaku penjualan dan peredaran minuman keras sehingga para pelaku tersebut akan menjadi jera dan tidak mengulangi lagi perbuatannya. Sedangkan dalam rangka penegakan Perda, unsur utama sebagai pelaksana di lapangan adalah Pemda. Dalam hal ini kewenangan tersebut diemban oleh Satuan Polisi Pamong Praja (Satpol PP). Satpol PP mempunyai tugas membantu Kepala Daerah untuk menciptakan suatu kondisi daerah yang tenteram, tertib, dan teratur, sehingga penyelenggaraan roda pemerintahan

${ }^{56}$ Wawancara dengan Sismadi, selaku Kasi Penindakan Satuan Polisi Pamong Praja (Satpol PP) Kabupaten Bantul, pada tanggal 14 Maret 2017.

${ }^{57}$ Wawancara dengan Anjar Arintaka Putra, selaku Kepala Bidang Penegakan Perda Satuan Polisi Pamong Praja (Satpol PP) Kabupaten Bantul, pada tanggal 15 Maret 2017.

${ }^{58}$ Wawancara dengan Andri Kusmiarno, selaku Staf Penyidik PPNS Satuan Polisi Pamong Praja (Satpol PP) Kabupaten Bantul, pada tanggal 15 Maret 2017.

59 Wawancara dengan Sri Hartati, selaku Staf Penyidik PPNS Satuan Polisi Pamong Praja (Satpol PP) Kabupaten Bantul, pada tanggal 15 Maret 2017. 
dapat berjalan dengan lancar dan masyarakat dapat melakukan kegiatannya dengan aman.

Berdasarkan hasil wawancara penulis dengan Teguh Nur Triono, selaku Kasi Pengkajian, Pengawasan dan Pengendalian Satuan Polisi Pamong Praja (Satpol PP) Kabupaten Bantul, ${ }^{60}$ diperoleh keterangan bahwa:

“...Peran Satpol PP adalah sebagai penegak Perda dalam hal ini Perda Nomor 2 Tahun 2012 tentang Pengawasan, Pengendalian, Pengedaran dan Pelarangan Penjualan Minuman Beralkohol di Kabupaten Bantul. Dalam pelaksanaannya apabila dalam kegiatan patroli atau operasi penegakan Perda patut dapat diduga ada pelanggaran Perda Nomor 2 Tahun 2012, maka barang bukti minuman beralkohol yang ditemukan dibuatkan surat penyerahan dan penitipan barang bukti kemudian data-data tersangka dipanggil untuk dimintai keterangan oleh PPNS yang ada di Satpol PP Kabupaten Bantul. Selanjutnya apabila memang melakukan pelanggaran terhadap Perda Nomor 2 Tahun 2012 dilakukan tindakan pro yustisi untuk diajukan ke depan sidang pengadilan. Sedangkan peran Kepolisian juga dapat bertindak sebagai penegak/aparat penegak hukum secara umum dan apabila terdapat pelanggaran terhadap Perda Nomor 2 Tahun 2012, maka Kepolisian melalui penyidiknya (Penyidik Umum Polri) dapat melakukan tindakan yustisi untuk mengajukan ke sidang pengadilan..."

Menurut Sismadi, selaku Kasi Penindakan Satuan Polisi Pamong Praja (Satpol PP) Kabupaten Bantul, ${ }^{61}$ diperoleh keterangan bahwa:

“... peran Satpol PP dalam hal penegakan Perda tentang minuman beralkohol adalah: a). Memberikan penyuluhan kepada masyarakat; b). Melakukan operasi terhadap penjualan minuman beralkohol; c). Menindak pelanggar Perda sampai ke ranah hukum. Sedang peran Kepolisian dan instansi terkait adalah melakukan koordinasi dan melakukan operasi gabungan. Peran Pengadilan Negeri adalah memeriksa berkas BAP dan menyidangkan pelanggar Perda. Sedangkan peran Kejaksaan Negeri adalah sebagai eksekutor hasil keputusan sidang pengadilan..."

Berdasarkan hasil wawancara penulis dengan Anjar Arintaka Putra, selaku Kepala Bidang Penegakan Perda Satuan Polisi Pamong Praja (Satpol PP) Kabupaten Bantul, ${ }^{62}$ diperoleh keterangan bahwa:

“...peran Satpol PP adalah menegakkan Perda dengan cara memberikan sosialisasi kepada warga masyarakat mengenai Perda Nomor 2 Tahun 2012 tersebut, mengadakan operasi dan patroli serta mengajukan tersangka pelanggar perda sampai ke ranah yustisi/pengadilan. Untuk peran kepolisian adalah mengadakan patroli dan operasi bekerjasama dengan Pemda, dan mengajukan tersangka

${ }^{60}$ Wawancara dengan Teguh Nur Triono, selaku Kasi Pengkajian, Pengawasan dan Pengendalian Satuan Polisi Pamong Praja (Satpol PP) Kabupaten Bantul, pada tanggal 14 Maret 2017.

${ }^{61}$ Wawancara dengan Sismadi, selaku Kasi Penindakan Satuan Polisi Pamong Praja (Satpol PP) Kabupaten Bantul, pada tanggal 14 Maret 2017.

62 Wawancara dengan Anjar Arintaka Putra, selaku Kepala Bidang Penegakan Perda Satuan Polisi Pamong Praja (Satpol PP) Kabupaten Bantul, pada tanggal 15 Maret 2017. 
pelanggar sampai ke ranah yustisi/pengadilan. Peran kejaksaan adalah membantu proses penuntutan tersangka untuk diajukan sampai ke pengadilan, dan sebagai eksekutor menerima hasil putusan sidang terkait dengan denda/kurungan. Sedangkan peran pengadilan adalah menerima berkas-berkas pengajuan sidang dari Satpol PP maupun dari Polisi dan menyidangkan tersangka dan memutuskan perkara tersebut..."

Hal senada diungkapkan oleh Andri Kusmiarno, selaku Staf Penyidik PPNS Satuan Polisi Pamong Praja (Satpol PP) Kabupaten Bantul, ${ }^{63}$ yang menyatakan bahwa:

“...peran Satpol PP adalah menegakkan perda dengan cara memberika sosialisasi kepada warga masyarakat, mengadakan operasi dan patroli, mengajukan tersangka pelanggar perda sampai ke ranah yustisi/pengadilan. Peran Polisi adalah mengadakan patroli dan operasi bekerjasama dengan Pemda, mengajukan tersangka pelanggar Perda sampai ke ranah yustisi/pengadilan. Peran Kejaksaan adalah membantu proses penuntutan tersangka untuk diajukan sampai ke pengadilan, sebagai eksekutor dalam menerima hasil putusan sidang terkait dengan denda dan kurungan. Sedangkan peran pengadilan adalah menerima berkas-berkas pengajuan sidang dari Satpol PP maupun dari Polisi, menyidangkan tersangka dan memutuskan perkara tersebut..."

Sedangkan menurut Sri Hartati, selaku Staf Penyidik PPNS Satuan Polisi Pamong Praja (Satpol PP) Kabupaten Bantul, ${ }^{64}$ diperoleh keterangan bahwa Satpol PP dan Kepolisian berperan sebagai penegak Perda sedangkan instansi terkait berperan sebagai lembaga pengawasan dan pembinaan.

Berdasarkan hasil wawancara penulis dengan Teguh Nur Triono, selaku Kasi Pengkajian, Pengawasan dan Pengendalian Satuan Polisi Pamong Praja (Satpol PP) Kabupaten Bantul, ${ }^{65}$ diperoleh keterangan bahwa razia minuman beralkohol dilakukan setiap kali kegiatan patroli maupun apabila ada informasi dari intelijen/informan atau dari pengaduan masyarakat. Menurut Sismadi, selaku Kasi Penindakan Satuan Polisi Pamong Praja (Satpol PP) Kabupaten Bantul, ${ }^{66}$ diperoleh keterangan bahwa razia minuman beralkohol dilakukan setiap bulan atau menurut situasi di wilayah, apabila diketahui terdapat penjual langsung dilakukan razia. Selanjutnya, hasil wawancara penulis dengan Anjar Arintaka Putra, selaku Kepala Bidang Penegakan Perda Satuan Polisi Pamong

${ }^{63}$ Wawancara dengan Andri Kusmiarno, selaku Staf Penyidik PPNS Satuan Polisi Pamong Praja (Satpol PP) Kabupaten Bantul, pada tanggal 15 Maret 2017.

${ }^{64}$ Wawancara dengan Sri Hartati, selaku Staf Penyidik PPNS Satuan Polisi Pamong Praja (Satpol PP) Kabupaten Bantul, pada tanggal 15 Maret 2017.

${ }^{65}$ Wawancara dengan Teguh Nur Triono, selaku Kasi Pengkajian, Pengawasan dan Pengendalian Satuan Polisi Pamong Praja (Satpol PP) Kabupaten Bantul, pada tanggal 14 Maret 2017.

${ }^{66}$ Wawancara dengan Sismadi, selaku Kasi Penindakan Satuan Polisi Pamong Praja (Satpol PP) Kabupaten Bantul, pada tanggal 14 Maret 2017. 
Praja (Satpol PP) Kabupaten Bantul, ${ }^{67}$ diperoleh keterangan bahwa razia minuman beralkohol bisa dilakukan setiap bulan atau triwulan. Hal senada diungkapkan oleh Andri Kusmiarno, selaku Staf Penyidik PPNS Satuan Polisi Pamong Praja (Satpol PP) Kabupaten Bantul, ${ }^{68}$ diperoleh keterangan bahwa razia minuman beralkohol biasa dilakukan setiap bulan atau triwulan.

Hal senada juga diungkapkan oleh Sri Hartati, selaku Staf Penyidik PPNS Satuan Polisi Pamong Praja (Satpol PP) Kabupaten Bantul, ${ }^{69}$ diperoleh keterangan bahwa razia minuman beralkohol di Kabupaten Bantul biasanya dilakukan 2 bulan sekali.

\section{Kesimpulan}

Berdasarkan hasil analisis dan pembahasan pada bab-bab terdahulu, berikut disajikan kesimpulan yang merupakan jawaban terhadap permasalahan dalam penelitian ini, yaitu: Pertama, Kendala yang ada dalam Implementasi Peraturan Daerah Nomor 2 Tahun 2012 tentang Pengawasan, Pengendalian, Pengedaran dan Pelarangan Penjualan Minuman Beralkohol di Kabupaten Bantul adalah masih minimnya sumber daya manusia di bidang intelijen guna memberikan masukan/informasi terkait peredaran minuman beralkohol; serta pemberian vonis denda yang tidak membuat efek jera bagi pelanggar Perda Nomor 2 Tahun 2012. Selain itu, kendala yang dialami dalam menegakkan Perda Nomor 2 Tahun 2012.

Kedua, Implementasi Peraturan Daerah Kabupaten Bantul Nomor 2 Tahun 2012 tentang Pengawasan, Pengendalian, Pengedaran dan Pelarangan Penjualan Minuman Beralkohol di Kabupaten Bantul belum berjalan sesuai dengan harapan dikarenakan sosialisasi yang tidak menyentuh hingga ke ranah masyarakat dan penjual sehingga mereka tidak mengerti mengenai adanya hukuman yang akan menjerat apabila melanggar perda tersebut. Selain itu juga dalam urusan perijinan yang memerlukan terlalu banyak syarat serta biaya yang tidak murah menyebabkan banyaknya penjual minuman beralkohol yang tidak mengurus perijinan. Sedangkan hal yang menyebabkan masih banyak terjadinya pelanggaran Perda Nomor 2 Tahun 2012 adalah kurangnya kesadaran hukum dan peran serta masyarakat dalam pengawasan pengedaran dan penggunaan minuman beralkohol.

\footnotetext{
${ }^{67}$ Wawancara dengan Anjar Arintaka Putra, selaku Kepala Bidang Penegakan Perda Satuan Polisi Pamong Praja (Satpol PP) Kabupaten Bantul, pada tanggal 15 Maret 2017.

${ }^{68}$ Wawancara dengan Andri Kusmiarno, selaku Staf Penyidik PPNS Satuan Polisi Pamong Praja (Satpol PP) Kabupaten Bantul, pada tanggal 15 Maret 2017.

${ }^{69}$ Wawancara dengan Sri Hartati, selaku Staf Penyidik PPNS Satuan Polisi Pamong Praja (Satpol PP) Kabupaten Bantul, pada tanggal 15 Maret 2017.
} 


\section{Pustaka Acuan}

Buku

Aji, Ahmad Mukri. "Hak dan Kewajiban Asasi Manusia Dalam Perspektif Islam," SALAM: Jurnal Sosial dan Budaya Syar-i, Volume 2, Nomor 2, (2015).

Aji, Ahmad Mukri; Yunus, Nur Rohim. Basic Theory of Law and Justice, Jakarta: Jurisprudence Institute, 2018.

HR, Ridwan. Hukum Administrasi Negara, Yogyakarta: UII Press, 2002.

Huda, Ni'matul. Hukum Pemerintah Daerah, Bandung: Nusa Media, 2012.

Kaloh, J.. Mencari Bentuk Otonomi Daerah, Jakarta: Rineka Cipta, 2002.

Maggalatung, A.S.; Aji, A.M.; Yunus, N.R. How The Law Works, Jakarta: Jurisprudence Institute, 2014.

Maggalatung, A Salman. "Hubungan Antara Fakta Norma, Moral, Dan Doktrin Hukum Dalam Pertimbangan Putusan Hakim," dalam Jurnal Cita Hukum, Vol. 2, No. 2 (2014).

Mertokusumo, Sudikno. Mengenal Hukum, Suatu Pengantar, Yogyakarta: Liberty.

Sunarno, Siswanto. Hukum Pemerintahan Daerah di Indonesia, Jakarta: Sinar Grafika, 2006.

Widodo, Joko. Analisis Kebijakan Publik, Malang: Bayumedi, 2007.

Winarno, Budi. Kebijakan Publik Teori dan Proses, Jakarta: PT Buku Kita, 2008.

Zahrotunnimah, Zahrotunnimah; Yunus, Nur Rohim; Susilowati, Ida. "Rekonstruksi Teori Komunikasi Politik Dalam Membangun Persepsi Publik," dalam Jurnal Staatsrecht: Indonesian Constitutional Law Journal, Volume 2, Nomor 2 (2018).

\section{Wawancara}

Wawancara dengan Alip Yuliana dan Sugiyono, selaku penjual minuman keras di Kabupaten Bantul, pada tanggal 17 Maret 2017.

Wawancara dengan Andri Kusmiarno, selaku Staf Penyidik PPNS Satuan Polisi Pamong Praja (Satpol PP) Kabupaten Bantul, pada tanggal 15 Maret 2017.

Wawancara dengan Anjar Arintaka Putra, selaku Kepala Bidang Penegakan Perda Satuan Polisi Pamong Praja (Satpol PP) Kabupaten Bantul, pada tanggal 15 Maret 2017.

Wawancara dengan Ismanto dan Gunawan, selaku penjual minuman keras di Kabupaten Bantul, pada tanggal 17 Maret 2017.

Wawancara dengan Sismadi, selaku Kasi Penindakan Satuan Polisi Pamong Praja (Satpol PP) Kabupaten Bantul, pada tanggal 14 Maret 2017.

Wawancara dengan Sri Hartati, selaku Staf Penyidik PPNS Satuan Polisi Pamong Praja (Satpol PP) Kabupaten Bantul, pada tanggal 15 Maret 2017.

Wawancara dengan Sri Widodo, selaku penjual minuman keras di Kabupaten Bantul, pada tanggal 17 Maret 2017.

Wawancara dengan Teguh Nur Triono, selaku Kasi Pengkajian, Pengawasan dan Pengendalian Satuan Polisi Pamong Praja (Satpol PP) Kabupaten Bantul, pada tanggal 14 Maret 2017. 